\title{
ACADEMIC PERSEVERANCE, CLASS ATTENDANCE AND STUDENTS' ACADEMIC ENGAGEMENT: A CORRELATIONAL STUDY
}

\author{
Okubanjo Anthony Oluremi \\ McPherson University, SerikiSotayo, College of Social and Management \\ Sciences, Department of Business Administration
}

\begin{abstract}
The study investigated academic perseverance and class attendance as correlates of students' academic engagement among secondary school students in ogun state. The study adopted survey design of expost-facto type.

Three instruments were used with one adopted and two designed by the researcher.

200 students participated in the study. Three hypotheses were formulated and tested at 0.05 level of significance using pearson product correlation matrix statistical method.

The study revealed among others that

(i) there is significant relationship between academic perseverance and academic engagement.

(ii) there is relationship between class attendance and academic engagement.
\end{abstract}

Keywords: Academic Perseverance, Class Attendance, Academic Engagement, Ogun State

\section{Introduction}

Education is a corner stone upon which the development and growth of any country is dependent upon. Any country that wants to develop should pay adequate attention to the education of her citizen. This probably made the Nigerian government at all levels paid special attention to the provision of educational opportunities to all Nigerians irrespective of tribe or location. The National Policy on Education (2004) confirmed that education is an instrument for effecting national development. Inspite of this, the attitude of Nigerian students towards education had left much to be desired. Many students were in school not necessarily because they were committed but just to please their parents or guardians. This led them into not being seriously involve in school activities otherwise referred to as academic engagement in 
this study. Non commitance of many of the students led to abysmal performance that had been source of concern to all stake holders in education (Fakunle 2010).

Academic engagement is the time and energy that students devote to educationally sound activities inside and outside of classroom and the policies and practices that the schools use to include students to take part in the activities (Kuh 2003).

Academic engagement are behaviours that signal serious psychological investment in class work which include being attentive in class, doing the assigned works, taking initiatives to raise and ask questions, partake in group activities and regular attendance at class. Academic engagement had been found positively related to objective and subjective measures of gain in general abilities and critical thinking (Hn\&Resper 2000; Pike, Kuh and Gonyen 2003). This implies that for any student to benefit immensely from school academic activities, such student should be academically involved.

Moreso, Aderson, Christenson and Lehr (2005), found out that parents have pivotal role to play in vostering their wards academic engagement (Ukwueze 2010) observed that bearing becomes effective process through listening, writing, asking question and contributing to discussion, brainstorming and working in group under the guidance of a teacher. This suggests that teachers also has role to play in enhancing students academic engagement. No wonder that Onyechere 2010 observed that students failure in external examinations could not be blamed on the students alone but also on teachers and other stake holders.

This notwithstanding, students themselves are more concerned and involved in the enhancement of their academic engagement than any other person. For any student to be involved in academic activities, such student should attend class, which possibly explains why class attendance is also considered in this study.

Class attendance is ability of students to be physically and psychologically present in the classroom. The student should be seen in class at the same time his/her soul should also be present. It is possible for student to be present but his/her mind be somewhere else or that the student engages in other things like, gisting, playing or copying note with little or no attention being paid to the teacher. Regular attendance in class in school (Chung 2004). It is an obvious fact that students that miss too many classes might not perform well academically.

Caviglia-Haris (2004) investigated that impact of mandatory attendance policy on students grades and found out positive impact.

Very close to class attendance is the academic perseverance on the part of the student. Kwong, Mokand Kwong (1997) defined perseverance at 
the ability of an individual to endure in the presence of deterrents. It is an attempt of an individual to press further inspite of difficulties. Academic perseverance therefore is the extent to which a student could continue engaging in academic activities inspite if difficulties or obstacles.

Mok and Kwong (1999) observed that persistence could be understood interms of individuals motivation, deterrents, personal dispositions, attitude, beliefs, social economic status etc.

Furrer and Skinner (2003) found out that teachers could influence student motivation thus improving student's perseverance through classroom reward structure. Apart from this, the type of people the students interacts with within the school setting could enhance both the class attendance and perseverance. This position is in line with Pieice and Sarason (1990) confirmed others acts as buffer to allowing people to show more self-reliance and tenacity in the face of obstacle.

Anderman (1999) concluded that feeling of relatedness, quality of teacher-student relationship, feeling of belongings, inclusion acceptance, interpersonal support have been found to be related to important academic outcomes which include self-efficacy, success expectation, achievement values, positive effect, interest in school and school engagement.

From the foregoing, it is obvious that many scholars had examined variables like, class attendance, perseverance and academic engagement.

However, non of the related literatures combined class attendance and perseverance to test their relationship with academic engagement as in this study. It is with this view in mind that this study set out to investigate whether there is correlation between academic perseverance, class attendance and academic engagement among senior secondary school students in Ijebu-North Local Government Area of Ogun State.

It was hypothesized that:

(i) There is significant relationship between academic perseverance and academic engagement.

(ii) There is relationship between class attendance and academic engagement.

(iii) There is significant relationship between class attendance and academic perseverance.

\section{Method}

\section{Design}

The study adopted a descriptive survey research of expost-facto type. This is because the researcher is just interested in the interaction between the predictor variables and the criterion variable. 


\section{Sample}

The target population for this study include all the senior secondary school students in Ijebu-North Local Government area of Ogun State. A sample of 200 students were randomly drawn from 10 randomly selected secondary school among 19 senior secondary schools in the local government area.

It follows from the above that 20 students were randomly selected from each of the schools.

\section{Instrumentation}

The study adopted three research instruments:

Academic engagement scale designed by (Joreskog 1971) and confirmed as valid by March \&O’Nell 1984 was adopted to collect information on academic engagement of students. It was an 11 items of 5 point likert scale type. The scale has reliability index of 0.72 .

Academic perseverance and class attendance questionnaires were self designed by the researcher. Academic perseverance has 8 items while class engagement contained 15 items. These instruments were initially 15 items each making 30 items, but after the two were subjected to factor structure, only 23 items reported earlier survived and those were the one used for the study.

Test-retest reliability was adopted for pilot study on 40 students who were not part of the selected sample but has the same characteristics with the sample. After two weeks, the retest was dome and the results revealed 0.81 , 0.68 respectively.

\section{Procedure}

The researcher visited the selected schools by himself, to administer the questionnaire on the first 20 SSS class students in each school. The fact that the administration was done by the researcher who guided the respondents and collect the questionnaire back after filling made 100\% success possible in retrieving the instruments. The data collected were analised using Pearson product correlation statistical method. 


\section{Result}

Table 1: Correlation matrix of the relations between academic perseverance and academic engagement.

\begin{tabular}{|c|c|c|c|}
\hline & & Academic Perseverance & Academic Engagement \\
\hline $\begin{array}{c}\text { Academic } \\
\text { Perseverance }\end{array}$ & Pearson & 1 & $.551\left(^{* *}\right)$ \\
\hline & Sig. (2-tailed) & & .000 \\
\hline $\begin{array}{c}\text { Academic } \\
\text { Engagement }\end{array}$ & Pearson & 200 & 200 \\
\hline & Sig. (2-tailed) & $.551\left(^{* *}\right)$ & 1 \\
\hline & N & 2000 & 200 \\
\hline
\end{tabular}

Results in Table 1 above revealed that there is a significant relationship between academic perseverance and academic engagement $(\mathrm{r}=$ $.551 ; \mathrm{p}<0.5$ ); the implication of this finding is that the higher the academic perseverance, the higher the academic engagement and the lower the academic engagement, the lower the academic perseverance.

Table 2: Correlation Matrix of the Relations between class attendance and academic engagement.

\begin{tabular}{|c|c|c|c|}
\hline & & Class Attendance & Academic Engagement \\
\hline $\begin{array}{c}\text { Class } \\
\text { Attendance }\end{array}$ & Pearson & 1 & $.616\left(^{* *}\right)$ \\
\hline & Sig. (2-tailed) & & .000 \\
\hline $\begin{array}{c}\text { Academic } \\
\text { Engagement }\end{array}$ & $\mathrm{N}$ & 200 & 200 \\
\hline & Pearson & $.616\left(^{* *}\right)$ & 1 \\
\hline & $\mathrm{N}$ & .000 & 200 \\
\hline
\end{tabular}

**Correlation is significant at the 0.01 level (2-tailed).

From the results in Table 2 above it was revealed that there is a significant relationship between class attendance and academic engagement $(\mathrm{r}=.616 ; \mathrm{p}<.05)$; the implication of this finding is that the higher the class attendance, the higher the academic engagement and vice versa. 
Table 3: Correlation Matrix of the Relations between class attendance and academic perseverance.

\begin{tabular}{|c|c|c|c|}
\hline & & Class Attendance & Academic Perseverance \\
\hline $\begin{array}{c}\text { Class } \\
\text { Attendance }\end{array}$ & Pearson & 1 & $.473\left(^{* *}\right)$ \\
\hline & Sig. (2-tailed) & & .000 \\
\hline & $\mathrm{N}$ & 200 & 200 \\
\hline $\begin{array}{c}\text { Academic } \\
\text { Perseverance }\end{array}$ & Pearson & $.473\left(^{* *}\right)$ & 1 \\
\hline & Sig. (2-tailed) & .000 & 200 \\
\hline & $\mathrm{N}$ & 200 & \\
\hline
\end{tabular}

**Correlation is significant at the 0.01 level (2-tailed)

From Table 3 above, the result stated that there is a significant relationship between class attendance and academic perseverance $(r=.473$; $\mathrm{p}<.05$ ); the implication of this finding is that the higher the class attendance, the higher the academic perseverance and vice versa.

\section{Discussion}

The result in table one revealed a significant correlation between academic perseverance and academic engagement. This result is not surprising since it is obvious that some with high level of perseverance is more likely to be engaged in whatever assignment he/she found him/herself doing. It is like wherever could be academically engaged could academically preserve or vis-à-vis. The outcome of this study is in line with that of Pike, Kuh and Gonyea (2003) that found positive relationship between academic engagement and objective and subjective measures which include perseverance. The result also corroborated Bannett andGarcisk (2006) who found out that high academic engagement while low academic perseverance contributed to low academic engagement.

The result in table two revealed that there is a significant relationship between class attendance and academic engagement. The result here is in line with Chung (2004) who found out that prerequisite for academic engagement. This implies that students with high level of call attendance are more likely to be highly involved in academic activities (academic engagement). It was also discovered that significant relationship existed between academic perseverance and class attendance. The result here is not surpising because regular attendance at class is in itself an act of academic perseverance. Whoever that could not persevere may have the tendency of not attending class regularly. The result in this study could also be supported by Furrer\& Skinner's view that teachers could inreturn improve students perseverance through classroom reward structure. It is obvious that only 
students could also attend classes regularly if there is mutual respect understanding between the teacher and the students.

From the findings of this study, it is clear that a strong relationship existed between academic perseverance, class attendance and academic engagement. Thus, for any student to achieve well in academic, such student should be able to persevere, attend class regularly and also be academically engaged.

\section{Recommendations}

Pursuant to the abysmal performance of students at various educational levels, which had in a way been a source of concern to all stake holders of education, it could be recommended based on the outcome of this study that:

Teachers should make the class less boring so as to encourage the students to attend regularly. Teacher should make themselves more assessable to their students. Parents should give necessary support to their wards interms of providing educational support materials such as payment of school fees, purchase of books, uniform, school bags and school sandals, since lack of all these could discourage students from attending classes.

Students on their part should make it a point of duty to attend classes regularly. They should not be easily discouraged whenever there was any obstacle or difficulty in course of their study and above all should be adequately involved in all academic activities going on in their classes in particular and in the school in general.

\section{References:}

Anderman, L.H. (1999). Classroom goal orientation, school belonging and social goals as predictors of students positive and negative effect following transition to middle school, journal of Research and development 32, 89-103. Bannett, R.C. \&Garcisk, C. (2006). Parental care after School Stress and Psychology well being. Journal of marriage and family 68 (1) 101-108.

Cavigla-Haris, J.L. (2004). Attendance rates and academic achievement. Do attendance and policy and class size have effects on students performance? Retrieved fron http: www.SM.com/ abstract $=605462$ on 26/7/2013.

Chung, C.J (2004). Impact of attendance, instructor contact and home work completion on achievement and equal educational opportunity.The report of consent decree monitoring team US District Court, Northern District Califonia.

Fakunle, D. (2010). Selected Counselling Strategies for promoting peaceable schools and good academic performance among Nigerian Students, Conference proceedings $30^{\text {th }}$ Annual National Conference of Counselling Association of Nigeria, vol 1, enugu 188-195. 
Furrer, C. \& Skinner, E. (2003).Sense of relatedness as a factor in children academic engagement and performing. Journal of educational psychology 95 (1) $148-162$

Kuh, G.D. (2003). Whatwerelearning about student engagement, NSSE Technical and Norms report, IndianUniversity Centre for post SecondarySchoolResearch and Planning 35 (2) Bloomington W. 24-32.

Kwong, T.M., Mok, Y.F., \&Kwong, M.L. (1997). Social factors and adult Learner: Motivation in re-entering higher education. International journal of life long education, 16 (6), 518-334.

Mok, Y.F. \&Kwong, T.M. (1999).Discriminating participants and non participants in continuing professional Education.International journal of life long Education 18 (6) 505-519.

Morese, A.B., Aderson, A.R. \& Christenson, S.H. \& Lehr, C.A (2005) promoting school completion through principal leadership style. (6) $9-13$

Onyechere, I. (2010). Season of Mass Failure.The Nation. Lagos: vintage press Ltd. 5 (1365), April 15, B1-B2.

Pike, G.R., Kuh, G.D \&Gonyea, R.M (2003).The relationship between institutional mission and students involvement and educational outcomes research in higher education 44 (2) 241-261.

Ukwueze, A.C. (2010). Negative Attitude to work and Adjustment problems of young Teachers in Secondary Schools; Implications for Counselling Conference proceedings for the $36^{\text {th }}$ Annual National Conference of the Counselling Association of Nigeria (CASSON) vol 1 Enugu 119-127 